\title{
МЕДИКО-СОЦІАЛЬНІ АСПЕКТИ ПРОБЛЕМИ НАДАННЯ ПАЛІАТИВНОЇ ДОПОМОГИ У РОДИНАХ ТЯЖКОХВОРИХ ТА ІНКУРАБЕЛЬНИХ ПАЦІЕТІВ
}

\author{
А. І. Смачило, Л. Ф. Матвї̈в, О. М. Качунь, Л. І. Іваськевич \\ Тернопільський національний медичний університет \\ імені І. Я. Горбачевського МОЗ Украӥни
}

\begin{abstract}
Паліативна допомога (Пд) - інноваційний для більшості країн світу, у тому числі й України, вид медичної допомоги. Зростання потреби розв’язання комплексу фізичних, психосоціальних і духовних проблем невиліковно хворих та їхніх родичів стало новим викликом для системи охорони здоров'я та поштовхом до розвитку інституцій Пд.

У роботі визначено соціальний профіль родичів, які доглядають за інкурабельними пацієнтами. Це переважно жінки працездатного віку, які змушені згорнути соціальну активність на фоні погіршення матеріальних доходів, мають відчуття постійного стресу, потребують допомоги у догляді й незадоволені медичним обслуговуванням своїх рідних, що підкреслює соціально-економічне значення проблеми і важливість розвитку інституцій Пд.

Разом із цим, виявлені високий рівень недовіри, скарги на байдужість і неналежне ставлення обслуговуючого персоналу, невдоволення потреб хворих в отриманні медичної та соціально-правової інформації вказують на недостатність знань і вмінь медпрацівників щодо специфіки комунікації із такими пацієнтами та їхньою родиною, а також протидії професійному вигоранню, характерному для представників хелперських професій.
\end{abstract}

\section{MEDICAL AND SOCIAL ASPECTS OF THE PROBLEM OF PROVIDING PALLIATIVE CARE TO THE FAMILIES OF TERMINALLY ILL AND INCURABLE PATIENTS}

\author{
A. I. Smachylo, L. F. Matviyev, O. M. Kachun, L. I. Ivaskevych
}

\section{Horbachevsky Ternopil National Medical University}

Palliative care (PC) is an innovative type of medical care for most countries of the world, including Ukraine. The growing need to address the complex of physical, psychosocial and spiritual problems of terminally ill patients and their relatives has become a new challenge for the health care system and a push for the development of PC institutions in Ukraine.

The study has identified the social profile of relatives caring for incurable patients. These are mainly working-age women who are forced to cease social activity amid worsening financial income; they are constantly stressed, in need of assistance in the care of their ill relative and are dissatisfied with the health care of their relatives, which emphasizes the socio-economic importance of the problem and the need of the development of PC institutions. At the same time, a high level of distrust, complaints on the indifference and improper attitude of the health care personnel, dissatisfaction of patients' needs in receiving medical, social and legal information were revealed. All this testifies to the lack of knowledge and skills of health care providers regarding the specifics of communication with such patients and their families, as well as counteracting the professional burnout characteristic of the helper professions.

Вступ. Згідно з даними фахівців Всеукраїнської громадської організації «Українська ліга сприяння розвитку паліативної та хоспісної допомоги», приблизно 1,5 млн хворих та членів їхніх родин кожного року потребують паліативної допомоги (ПД), головною метою якої $\epsilon$ полегшення фізичного страждання хворих та надання їхнім родинам психологічної та духовної допомоги і підтримки [1]. Проте сьогоденні реалії свідчать, що задоволення таких потреб українська медицина не може забезпечити в повному обсязі [2]. Це відбувається з декількох причин, серед яких нестача працівників, які мають спеціальну підготовку, недостатність спеціалізованих установ, а також недоступність якісних методів знеболювання для пацієнтів. 
Обслуговування інкурабельних хворих, з яким, згідно з сучасними європейськими стандартами, стикається кожен медичний працівник [3, 4], має свою специфіку та вимагає від медперсоналу спеціальних знань з різних галузей клінічної медицини, психології, фармакології, навичок спілкування з пацієнтом та його близькими, вміння протидіяти та долати наслідки професійного вигорання, працювати в складі мультидисциплінарної команди з фахівцями-немедиками: соціальними працівниками, психологами, волонтерами, священнослужителями та ін.

Мета роботи: дослідити медико-соціальні аспекти проблеми надання паліативної допомоги у родинах тяжкохворих та інкурабельних пацієнтів.

Основна частина. Наше дослідження було присвячене вивченню медико-соціальних характеристик родичів невиліковно хворих пацієнтів при наданні паліативної допомоги шляхом проведення анонімного соціологічного дослідження за спеціально розробленою програмою. Анкета містила запитання стосовно віку, статі, місця проживання, доходів, рівня освіти, побутових умов, сімейного стану, соціальнопсихологічних взаємин, поведінкових чинників індивідуального способужиття, самооцінки здоров'я тощо.

обробка отриманих результатів медико-соціологічних досліджень потребувала формування комп'ютерної бази даних на основі Microsoft Excel, де матеріали групувались за контингентом вивчення (хворі, родичі, медпрацівники різного ступеня контакту з інкурабельними пацієнтами), місцем проживання (міські, сільські мешканці), статтю (чоловіки, жінки) та віком (до 30 років, 30-39, 40-49, 50-59, 60 років і старші). Статистичну обробку отриманого матеріалу проводили шляхом розрахунку частоти поширення

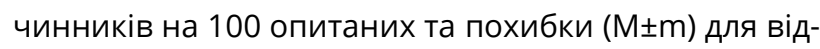
носних величин за загальновідомою формулою [5].

Очевидно, що родичі невиліковно хворих пацієнтів $\epsilon$ вагомими учасниками та об'єктами паліативної допомоги. Проведено анкетування 102 респондентів, які у більшості були міськими мешканцями $(67,1 \pm 3,9) \%$ проти $(32,9 \pm 3,9) \%$ жителів сіл (p<0,001).

Поділ опитаних за статтю - традиційний для таких життєвих ситуацій, адже догляд за хворими родичами, головним чином, здійснюють саме жінки $(69,5 \pm 3,8) \%$ проти $(30,5 \pm 3,8) \%$ чоловіків.

При цьому більшість опитаних мали значний стаж такого догляду: $(44,1 \pm 3,6)$ \% респондентів здійснювали його в межах від декількох місяців до року, а $(26,2 \pm 3,0) \%$ - взагалі декілька років.
Варто вказати, що більшість $(92,8 \pm 1,3)$ \% опитаних родичів невиліковних хворих була працездатного віку. Зрозуміло, що наявність тяжкохворого члена родини, необхідність доглядати чи організовувати догляд за ним, психологічні переживання знижують продуктивність праці, а отже, поглиблюють соціальноекономічні збитки.

Лише $(68,2 \pm 2,8)$ \% опитаних працювали, у тому числі кожен десятий $(7,9 \pm 2,3) \%$ мав тимчасову роботу. Третина $(31,0 \pm 3,8) \%$ респондентів не працювала взагалі. Головними причинами їхньої незайнятості були: пенсійний статус (32,3 \%), безробіття (23,4 \%), ще 23,2 \% займались веденням домогосподарства, 9,2 \% - студенти і 2,0 \% - інваліди. Привертає увагу та обставина, що практично кожен десятий (9,0 \%) незайнятий респондент заявив, що не працює через необхідність догляду за своїм тяжкохворим родичем.

Крім соціально-економічних збитків для держави, поява невиліковно хворого призводить до значного погіршення матеріального добробуту на сімейному рівні. Все це на фоні невисокого рівня благополуччя, коли навіть до появи в сім'ї некурабельного хворого кожен п'ятий $(22,1 \pm 3,4) \%$ з респондентів вважав власні статки низькими. За результатами оцінок матеріального добробуту опитаними родичами після встановлення діагнозу невиліковного захворювання їхнім рідним визначено, що розглянутий показник зріс удвічі до $(41,4 \pm 4,1) \%$. І навпаки, частка тих, які оцінювали власні доходи до і після появи в родині тяжкохворого як середні та вищі середніх, знизилась з $(72,3 \pm 3,7) \%$ і $(4,8 \pm 1,8) \%$ до $(55,2 \pm 4,1) \%$ та $(3,5 \pm 1,5)$ \% відповідно.

Опитані родичі, як і пацієнти, також мали досить високий рівень освіти: майже третина $(29,5 \pm 3,8) \%$ з них мала вищу освіту, середню спеціальну - $(48,6 \pm 4,1) \%$ та ще п'ята частина $(21,9 \pm 3,0) \%$ респондентів - середню освіту.

У результаті дослідження, встановлено, що лише $(10,3 \pm 2,5)$ \% з опитаних родичів інкурабельних хворих проживали в комфортних умовах, більшість $(80,8 \pm 3,3) \%$ - у задовільних і кожен десятий $(8,9 \pm 2,4) \%$ респондент, незалежно від віку, статі та місця проживання, скаржився на незадовільні умови проживання.

При аналізі сімейного стану показано, що більшість опитаних родичів невиліковно хворих пацієнтів перебуває у шлюбі $(71,9 \pm 3,7) \%$, кожен десятий - розлучений $(13,0 \pm 2,8) \%$, ще $(8,2 \pm 2,3) \%$ - ніколи не були одружені та $(6,8 \pm 2,1) \%$ - овдовілі.

Характеризуючи свої внутрішньосімейні стосунки, третина $(35,6 \pm 4,0)$ \% респондентів назвала їх добро- 
зичливими, більш як половина $(56,2 \pm 4,1) \%$ оцінювала стосунки в сім'ї як задовільні. Проте досить високою була частка тих, які скаржились на конфліктні стосунки в родинах - практично кожен десятий $(8,2 \pm 2,3) \%$. Однією із можливих причин цього, на наш погляд, може бути саме психотравмувальний вплив появи в сім'ї невиліковно хворого.

Також із встановленням у хворих діагнозу невиліковної недуги більшість їхніх родичів $(72,5 \pm 3,7) \%$ змушена була згорнути й свою звичну соціальну активність (відвідування театрів, кіно, гуртків, церкви, зустрічі з друзями тощо). Однією із причин цього може бути високий рівень відчуття відповідальності за тяжкохворого члена своєї сім'ї $(93,8 \pm 2,0) \%$, а також недосконалість системи ПД у нашій державі, коли значну частку обов'язків із догляду за такими хворими змушені на себе брати їхні родичі. Як ілюстрація, більшість $(70,5 \pm 3,8)$ \% респондентів почувалися самотніми в боротьбі за життя дорогої для них людини. У результаті майже половина $(44,8 \pm 4,1) \%$ респондентів вказала, що потребує підтримки психолога. Водночас досить вагома частка $(46,2 \pm 4,1) \%$ опитаних родичів просто не знала, де вона може отримати допомогу такого роду, яка, як відомо, $\epsilon$ важливою складовою паліативної допомоги.

Такий тяжкий психологічний стан, на фоні практично не сформованої системи психологічної допомоги, культурних стереотипів (психолога плутають з психіатром) тощо, може бути додатковим чинником, що спонукає респондентів шукати шляхи «зняття стресу», зокрема через шкідливі звички. Третина $(32,9 \pm 3,9) \%$ опитаних родичів зазначила, що курять, і майже така ж частка $(29,7 \pm 3,8) \%$ - регулярно (декілька разів на місяць і частіше) вживає алкоголь. Головним чином це респонденти чоловічої статі $(p<0,001)$, серед яких курили $(76,7 \pm 6,4) \%$ проти $(14,6 \pm 3,5) \%$ і досить часто вживали алкоголь $(60,5 \pm 7,5) \%$ проти $(16,7 \pm 3,7) \%$.
Сказане може бути поясненням, чому абсолютна більшість $(92,4 \pm 2,2)$ \% респондентів потребувала допомоги із догляду за невиліковними хворими.

У програму дослідження входило також вивчення думки цієї групи респондентів і щодо постачальників окремих складових догляду за інкурабельними хворими. Як видно із даних таблиці 1, опитані родичі у більшості випадків (40,6-62,2 \%), крім справляння фізіологічних потреб та зміни постелі (26,2-29,2 \%), вважали це своїм обов'язком. На думку респондентів, крім них, значну частину функцій з догляду має забезпечувати молодший медичний персонал (39,9-73,1%) та МСMO (22,9-44,1\%).

Внесок спеціально навченого персоналу (табл. 1) оцінювали родичі досить низько (16,7-25,9\%), можливо тому, що вони з ним не стикались на практиці й очевидно не знали про існування такого. Адже абсолютна більшість $(95,5 \pm 1,5)$ \% респондентів при подальшому опитуванні була переконана в необхідності володіння медичними працівниками спеціальними знаннями та навичками з догляду за невиліковними хворими.

Зовсім незначна частка респондентів знала й про можливу участь в догляді за невиліковними хворими волонтерів (8,3-20,3 \%) та соціальних працівників (0,7-6,3\%). У той же час, більшість $(78,5 \pm 3,4) \%$ родичів невиліковно хворих визнавала надзвичайну потребу в допомозі зі сторони соціальних служб. І знову - лише третині $(36,1 \pm 4,0) \%$ респондентів було відомо, де можна її отримати.

Необхідно акцентувати, що організаційна специфіка паліативної допомоги, зазвичай довготривалої, включає не тільки стаціонарне лікування.

Зрозуміло, що в домашніх умовах, на фоні не сформованої системи ПД, основний тягар догляду лягає на плечі родичів. Очевидно тому, більшість $(63,2 \pm 4,0) \%$ респондентів з їх числа вказала, що має потребу в спеціальних знаннях із догляду за тяжкохворими, а

Таблиця 1. Оцінка опитаними родичами невиліковно хворих пацієнтів поділу обов'язків із догляду за невиліковними хворими (на 100 опитаних)

\begin{tabular}{|l|c|c|c|c|c|c|}
\hline \multirow{2}{*}{$\begin{array}{c}\text { Складові догляду } \\
\text { за інкурабельними } \\
\text { хворими }\end{array}$} & \multicolumn{5}{|c|}{ Виконавці } \\
\cline { 2 - 7 } & родичі & Мсмо & МСБМо & $\begin{array}{c}\text { спеціально навчений } \\
\text { персонал }\end{array}$ & $\begin{array}{c}\text { соціальні } \\
\text { працівники }\end{array}$ & волонтери \\
\hline Перевдягання & 62,2 & 38,9 & 53,5 & 23,6 & 2,8 & 18,8 \\
\hline $\begin{array}{l}\text { Справляння фізіо- } \\
\text { логічних потреб }\end{array}$ & 29,2 & 22,9 & 61,1 & 16,7 & 0,7 & 8,3 \\
\hline Проведення туалету & 40,6 & 32,9 & 55,9 & 21,0 & 2,8 & 14,0 \\
\hline Годування & 58,7 & 44,1 & 39,9 & 25,9 & 6,3 & 20,3 \\
\hline Піднімання & 44,4 & 41,7 & 56,9 & 23,6 & 6,3 & 18,8 \\
\hline Зміна постелі & 26,2 & 35,2 & 73,1 & 17,9 & 2,8 & 14,5 \\
\hline
\end{tabular}


$(53,5 \pm 4,2) \%$ - хотіли 6 пройти з цією метою необхідне навчання.

Можливими причинами цього $є$ й те, що більшість респондентів не зовсім задоволена або й зовсім незадоволена різними складовими медичного обслуговування їхніх невиліковно хворих рідних. Опитаних родичів, як зрештою й самих невиліковних хворих, найбільше турбували проблеми, пов'язані з фінансовим забезпеченням сфери Пд, а саме: незадовільна забезпеченість медикаментами (51,8 \% повністю негативних оцінок) та матеріалами з догляду (46,1\%), а також харчуванням (30,5 \%) і умовами перебування хворих у закладах охорони здоров'я (22,0%). Крім цього, родичі пацієнтів характеризувались досить високим рівнем недовіри до медичного персоналу (18,4 \% зовсім не довіряли, а 70,9 \% - частково) і якістю догляду за їхніми рідними загалом (14,2 \% та 75,9 \% відповідно).

Респондентів частіше турбувала неорганізованість в роботі медичних працівників, особливо молодшого медперсоналу (14,9 \% повністю незадоволених і 74,5 \% - частково), який безпосередньо здійснює більшість функцій з догляду за хворими.

Варто зазначити, що оцінки родичів суттєво відрізнялися залежно від місця перебування їхніх хворих членів сімей $(p<0,05)$. У хоспісі практично не було зовсім негативних оцінок, за винятком незадоволеності харчуванням (7,0 \%) та недостатньою чіткістю роботи молодших спеціалістів із медичною освітою (2,3 \%) та молодшого медперсоналу (2,3 \%).

Так само відрізнялись за місцем опитування і преференції родичів щодо майбутнього місця відходу із життя у випадку невиліковного захворювання

\section{СПИСОК ЛІТЕРАТУРИ}

1. Вороненко Ю. В. Створення системи паліативної і хоспісної допомоги в умовах реформування охорони здоров'я в Україні: медичні і соціальні аспекти [Електронний ресурс] / Ю. В. Вороненко, Ю. І. Губський, А. В. Царенко // Охорона здоров'я і суспільство. - 2014. - № 1 (2). - С. 63-75. - Режим доступу : http://nbuv.gov.ua/j-pdf/ nauipr_2014_1_11.pdf.

2. Чайковська В. В. Сучасні стратегії розвитку медикосоціальної допомоги населенню літнього віку України / В. В. Чайковська // Східноєвропейський журнал громадського здоров'я. - 2012. - № 1. - С. 281.

3. Заблоцька І. М. Особливості роботи сімейної медсестри з пацієнтами похилого і старечого віку / І. М. Заблоцька, О. І. Антонишин // Східноєвропейський журнал
( $<<0,001)$. У цілому більшість $(68,1 \pm 3,9) \%$ респондентів, як і опитані пацієнти, висловила бажання завершити свій життєвий шлях вдома. Практично кожен четвертий $(17,4 \pm 3,2)$ \% обрав хоспіс, причому цей показник сформувався знову, головним чином, за рахунок тих опитаних родичів, чиї хворі члени сімей перебували в цьому медичному закладі $(45,5 \pm 7,5)$ \% проти поодиноких випадків у ЦМКЛ та ООД. Лише троє із 146 респондентів хотіли 6 померти в лікарні, що в черговий раз підкреслює загальну незадоволеність доглядом за інкурабельними пацієнтами у не призначених для цього відділеннях і лікарнях. Необхідно зазначити, що попри ці всі відповіді тільки для кожного п'ятого $(20,8 \pm 3,4) \%$ родича невиліковно хворого місце смерті не мало значення.

Висновки. 1. Соціальний профіль родичів, які доглядають за інкурабельними пацієнтами (переважно жінки, працездатного віку, які з появою в родині невиліковно хворого, змушені згорнути соціальну активність, що супроводжується погіршенням матеріальних доходів удвічі та відчуттям постійного стресу; абсолютна більшість потребує допомоги у догляді і незадоволена медобслуговуванням своїх рідних), вказує на економічні збитки для держави і важливість розвитку інституцій пД.

2. Високі рівні недовіри, незадоволення потреб в інформації, ставленням обслуговуючого медичного персоналу, його байдужістю свідчать про недостатність знань медичного персоналу щодо специфіки комунікацій із невиліковно хворими пацієнтами і протидії професійному вигоранню, що потрібно враховувати при підготовці медичних кадрів для сфери паліативної допомоги.

громадського здоров'я (спеціальний випуск) : матеріали V з'ізду спеціалістів з соціальної медицини та організації охорони здоров'я України, м. Житомир, 11-12 жовтня 2012 p. - 2012. - C. 40-41.

4. Palliative care in long-term care settings for older people [Electronic resource] / EAPC Taskforce 2010-2012. Report. January 2013. - 73 p. - Access mode : http://www.eapcnet.eu/ Portals/0/Organization/Long\%20term\%20care\%20settings/ Fi nalReportLongTermCareSettings_2013.pdf.

5. Forthofer R. N. Biostatistics: A Guide to design, analysis, and discovery / R. N. Forthofer, E. S. Lee, M. Hernandez. Amsterdam, etc.: Elsevier Academic Press, 2007. - 502 p. 